\title{
Idejni slojevi prosvjetiteljstva i kršćanstva u Relkovićevu Satiru
}

\author{
Krunoslav Matošević*
}

\begin{abstract}
Sažetak
Rad tematizira jedno od najvažnijih književnih ostvarenja hrvatskog prosvjetiteljstva, djelo Satir iliti divji čovik Matije Antuna Relkovića. U prvom se dijelu rada donosi kratak životopis autora i lokalizacija njegova stvaralaštva s popisom najvažnijih djela. Najveći dio rada pripada prikazu prosvjetiteljskih elemenata, koji su u djelu obrađeni kroz društvena, moralna i kulturna pitanja. U raznim djelima koja su u svojoj osnovi svjetovne tematike ipak možemo uočiti i isticanje različitih kršćanskih motiva, što je slučaj i sa Satirom, pa ce se u ovom radu prikazati elementi katoličke obnove prisutni u djelu. U četvrtom poglavlju slijedi općeniti prikaz socijalnih, idejnih i svjetonazorskih sastavnica djela kroz koje će se pokazati da su dominantne sastavnice vjera u mogućnost promjene čovjekova bića obrazovanjem te uvjerenje o moralno-etičkim vrijednostima škole $i$ školovanja, iz čega proizlazi da se Relkovićev moderni svjetonazor i moderno videnje čovjeka ne sukobljava s religijskim aspektima.

Ključne riječi: Relković, Satir, prosvjetiteljstvo, katolička obnova, svjetonazorski koncept
\end{abstract}

\section{Uvod}

Prema književnoj historiografiji i kritici, tijekom 18. stoljeća hrvatska književnost gubi na svojem umjetničkom značaju, a kao jedno od njezinih najvažnijih obilježja postaju elementi pučke književnosti, što joj je omogućilo i pojednostavilo recepciju u širim društvenim krugovima. Kako navodi Kolumbić, »najučeniji ljudi i dobri književni djelatnici pisali su na latinskom jeziku, otuđivali su se od narodnog književnog izraza. To međutim nije smetalo da se najčešće ti isti ljudi po svojim duhovnim nagnućima uključe u zahtjeve i potrebe vremena, koje je prije svega isticalo prevlast razuma nad osjećajem i maštom, prednost didaktičkog cilja nad estetskim užitkom. «1 Književna djela s prosvjetiteljskim elementima u Hrvatskoj se javljaju relativno rano, a upravo je jedno od njih i Relkovićev Satir.

* Krunoslav Matošević, mag.educ.philol.croat. E-pošta: kruno.matosevic26@gmail.com

1 Nikica Kolumbić, Didaktičnost kao dramaturška komponenta hrvatske prosvjetiteljske drame, Dani hvarskog kazališta V (XVIII. stoljeće), Split, 1978, 98-120. 


\section{1. Život i književni rad Matije Antuna Relkovića}

Matija Antun Relković rodio se 1732. godine u Svinjaru (današnji Davor). Otac mu je bio gradski časnik koji ga je, nakon što je otišao u rat u Italiju 1741. godine, ostavio u franjevačkom samostanu u obližnjem Cerniku. Tamo je Relković učio latinski, a nauke (gramatiku) nastavio je u Ugarskoj. Kada mu je bilo 16 godina, otišao je u vojsku gdje se probio do čina kapetana. Kao časnik brodske pukovnije sudjelovao je u sedmogodišnjem ratu, gdje je zarobljen. Zatočen u Frankfurtu na Odri vrijeme je ispunjavao čitajući i učeći jezik. U zatočeništvu je napisao knjigu Satir iliti divji čovik, kojom je »izišao pred svoj narod sa izrazito određenim programom: prosvjeta vala da pridigne zapuštenu Slavoniju $«,{ }^{2}$ te ju je objavio u Dresdenu 1762. godine. Drugo izdanje, znatno prošireno (s 1.938 na 3.498 stihova) te u odnosu na prvo dopunjeno predgovorom i nekolicinom proznih umetaka, objavljeno je u Osijeku sedamnaest godina kasnije. Osim Satira, objavio je i Novu slavonsku i nimačku gramatiku (1767.). Budući da je govorio četiri jezika, većina ostalih djela prevodilačke je naravi. U skladu s Relkovićevom prosvjetiteljskom crtom i ta su djela namijenjena odgoju i obrazovanju domaćeg čovjeka: Ćudoredne pripovidke Pilpaj-bramine indijanskog mudroznanca iliti vladanje velikih i malih za one, koji rado ćute i pripoviedaju pripovjedke, iz francuzkoga u slavonski jezik prenešene (prema Vinkovačkom rukopisu objavljeno s još nekim djelima 1875. u Senekovićevu izdanju, gdje se u naslovu navodi 1767. godina, koja nije potvrđena kao godina objavljivanja), Prva i pomnjivo ispisana ovčarnica (1776.), Postanak narodne pravice (1794.), Nek je svašta ili sabranje pametnih riči (1795.) te Ezopove fabule (1804.). Zbog teme rada, iznimno je važno spomenuti i tiskani prvijenac Slavonske libarice s lipimi molitvicami i naukom krstjanskim nakitite (1761.), kojim je autor također želio u svojem narodu proširiti prosvjetiteljske ideje i učvrstiti kršćanski nauk. Relković je umro 1798. godine u Vinkovcima. Grob mu se nalazi na vinkovačkom groblju, gdje mu je spomenik napravio Ivan Rendić, a nadgrobni epigram napisao Ivan Trnski.

\section{Prosvjetiteljski elementi u Satiru iliti divjem čoviku}

U filozofiji, kulturnoj povijesti i povijesti političkih ideja 18. stoljeće poznato je kao razdoblje prosvjetiteljstva koje je donijelo jednu od najvećih revolucija u povijesti čovječanstva — duhovnu revoluciju iz koje će proizići neke temeljne moderne kulturne i političke institucije, ${ }^{3}$ a temeljne su mu značajke povjerenje u um i spoznatljivost svih prirodnih i društvenih pojava. Poznato je da se Relkovićev Satir tumači kao najvažnije djelo prosvjetiteljstva u Slavoniji, ali i u Hrvatskoj općenito. Po načinu kako ocrtava čovjeka, kako tumači njegov mentalitet i individualitet, kao i po eksplikaciji i razumijevanju uvjeta čovjekove socijalne pri-

2 Tomo Matić, Djela Matije Antuna Relkovića, Stari pisci hrvatski, knj. 23, Zagreb, 1916, 5.

3 Slaven Ravlić, Prosvjetiteljstvo i enciklopedija: dva prosvjetiteljstva i dvije enciklopedije, Studia lexicographica, 2013, 7, 13, 2, 35. 
padnosti i čovjekove socijaliziranosti, Satir je inovativno i posve specifično djelo u kontekstu hrvatske kulture 18. stoljeća. ${ }^{4}$ Sama je fabula jednostavna: glavni lik, mitološki Satir, dolazi u Slavoniju, upoznaje se s tamošnjim prilikama i, nezadovoljan viđenim, kritizira »zle turske običaje«, kojih se Slavonci nisu bili oslobodili ni nekoliko desetljeća nakon izgona Turaka. U ozračju općeprosvjetiteljskog duha svojeg vremena Satir ne propušta priliku poučiti slavonske seljake što nužno moraju poduzeti kako bi se otrgnuli kako od tih »zlih turskih«, tako i vlastitih »loših običaja i navika«. Stoga im daje poduke i savjete o kršćanskom moralu i životu, obitelji, radu, uzgoju stoke, stanovanju, zemljoradnji, obrtništvu itd.

Djelo obuhvaća čitav kompleks društvenih, moralnih i kulturnih pitanja, među kojima posebno mjesto zauzima odgoj omladine — Relković poučava zaručnika i zaručnicu uoči vjenčanja te se osvrće na štednju, marljivost, poštenje, molitve, ljubav i druge temelje dobre obitelji. U poglavlju naslovljenom Od Gazdaluka (stihovi 1947-2218) kritizira slabo sagrađene kuće, kuće bez namještaja, držanje svinja koje zimi pojedu žito, a od kojih nema koristi jer ljeti stradaju od kuge. Kritizira se slabo timarenje krava, koje nemaju zimi ni staje, nego ih stave u šljivik, te savjetuje da se sagrade staje i da se kravama daju posije i sol, pa ce one davati mlijeka. Kritizira se i pečenje rakije, zbog koje se zapušta poljodjelstvo. Ismijava se način oranja na koje se ide prekasno, kad je sunce već visoko na nebu, i to s rakijom, kao na zabavu, te se navodi kako jedan nadničar u Njemačkoj, Šleskoj i Saskoj više (po)ore sam s kobilom ili kravom nego u Slavoniji petorica s deset volova ili konja. Na odgovor Slavonca da mu zemlja ne valja Satir, odnosno Relković, odgovara da zemlju treba njegovati i gnojiti i da nema zemlje koja ništa ne valja, što je učenje nizozemskih poljodjelaca koji su već tada bili na dobru glasu. Relković piše da su o obrađivanju zemlje napisane knjige pa, kada bi Slavonac znao čitati, mogao bi dosta saznati. Opet ističe da treba ići u školu, jer da se sada u svijetu vlada po knjigama te da se ne može biti ni vojnik, ni svećenik, ni trgovac, ni poslenik ako se ne zna čitati. Stoga pisac, kako bi popravio to loše stanje u kojem vladaju zli turski hadeti i turske skule, nastoji oživjeti moralne, odnosno kršćanske norme svojih predaka. Uz savjete o rješavanju ekonomskih i agrarnih problema, to je zapravo jedan od triju temeljnih didaktičkih ciljeva njegova djela.

Autor progovara Satirovim glasom. Satir objašnjava Slavoncima zbog čega su toliko zaostali u odnosu na druge europske narode:

Sto godina i pedeset biše, — jedni kažu, da ima i višje, — što nevirnik zemljom upravljaše, il, da reknem bolje, rasipaše. Jer dok tako skupa pribivaše turske kuće i krstjanske vaše, dok se žene s bulama poznaše, dok se dica s Turadma igraše, dok se, reko, zajedno vladaše, dotle Turci zao izgled daše. Običaje lipe ostaviše, a poganske po malo primiše (175-186).

4 Dunja Fališevac, Mjesto Satira u hrvatskoj epici i književnoj kulturi 18. stoljeća, u: Tomislav Bogdan (ur.), Matija Antun Relković i Slavonija 18. stoljeća, Zagreb - Davor, 2000, 118. 
Relković pomno nabraja i opisuje te zle turske hadete. To su:

1. Divani i posila s Turcima. Za vrijeme Vojne krajine, tj. u Relkovićevo doba, redovito su se održavala i posijela i divan, koji se strogo branio i kažnjavao s 40 batina. ${ }^{5}$ Posilo je, prema Relkoviću, običaj da se žene okupljaju pred kućom, na sokaku, pa po cijeli dan ogovaraju i pričaju isprazne priče. Satir nabraja sve loše strane takve navade koja dovodi do svađe, nesloge, zavisti, mržnje, lijenosti i bahatosti. Muškarci pak odlaze na divane, tj. po cijeli dan sjede, piju i puše u mehanama, dok ih kod kuće čekaju brojni neobavljeni poslovi.

2. Kolo. Kršćanske djevojke preuzele su turski običaj, jal kod Muje jal njegove Fate (192), da nedjeljom odlaze u kolo, gdi se uče igrat $i$ svakakve lakrdije pivat (407-408), umjesto da idu u crkvu na misu, Boga moliti, pjevati litanije i učiti vjeronauk. Potom ih kori neka se okanu takvih turskih skula jer je kolo smišljeno od vraga. Da bi to potvrdio, najvjerojatnije izmišlja priču o postanku kola, u kojoj na krajnje blasfemičan način govori o islamu i muslimanima:

Vi znadete, da je turski zakon iznesao Muhamed napokon a vrag mu je u pomoći bio, dok je lipše stvari izmislio, kojegod su lagane po tilo, medu njima i kolo je bilo.

\author{
Zato Turci najprvo počěse, \\ Muhamedu na grobu igraše, \\ za ukazat nikoje veselje \\ Muhamedu svome na poštenje. \\ Vidiš, dakle, da je od Turaka \\ došlo kolo, — da zla komšiluka! (607-618).
}

3. Psovke. Mladi naučiše od Turaka te počeše psovati vjeru, dušu, dasku $i$ grobnicu, oca, majku i stražnjicu.

4. Ašikovanje i nemoral među mladima: Nesta stida kod ženskoga spola s turskog prela i s turskoga kola (203-204).

5. Gubitak poštovanja prema starijima i prema roditeljima.

6. Čaranje, gatanje i svakojake prevare turskih bula. Svim tim poganskim običajima, koji imaju dubok korijen i teško ih je uništiti Turci posve otrovaše Slavoniju (165-214).

$\mathrm{Na}$ iste, ali i neke druge turske hadete obrušava se Relković na još mnogim mjestima u Satiru. Tako više puta spominje loš odgoj ženske djece (1515-1542), proricanje, gatanje, crnu magiju i druge čarolije koje Slavonke naučiše od turskih bula (1570-1596), kao i običaj Slavonaca da po turski sjede i jedu (1975-1976).

Satir je prije svega didaktičko djelo napisano u duhu europskog prosvjetiteljstva te stoga vrvi brojnim moralnim poukama i opomenama, čiju strogost Relković katkada ublažava prisnim i šaljivim obraćanjem Slavoncu s moj dragi pobro, moj dobri Slavonče, moj dragi Slavonče i sl. Nasuprot tomu, svaki put kad govori o Turcima njegovi vrijednosni sudovi, jezik i frazeologija dobivaju prizvuk neskrivene netrpeljivosti. Uzroci Relkovićeva odbojna stava spram svega što je tursko proizlazili su iz toga što je, kao austrijski časnik, u njima vidio najvećeg ne-

5 Ružica Pšihistal, Kako čitati Satira?, u: Tomislav Bogdan (ur.), Matija Antun Relković i Slavonija 18. stoljeća, Zagreb — Davor, 2000, 149. 
prijatelja Habsburške Monarhije. Bio je odgojen u snažnom kršćanskom duhu pa je u Turcima prepoznavao ne samo neprijatelje po oružju, nego i širitelje islama.

U prvom izdanju Relkovićevo je prosvjetiteljstvo povezano s prosvjetiteljstvom Friedricha Velikog, koji se dopisivao s Voltaireom, preuzevši velik dio građe iz francuskog prosvjetiteljstva.

Nakon prvog, dresdenskog izdanja, Relković počinje uviđati da stvari u Slavoniji kreću na bolje. Stoga u drugom, osječkom izdanju Slavonac odpiva u verše Satiru (1779.), izvještavajući ga o promjenama koje su se dogodile od njegova prvog posjeta Slavoniji. Na taj se način među njima uspostavlja dijalog. Između ostalog, Slavonac kaže da već ima uređenu kuću s kompletnim namještajem kojeg u tursko doba nije koristio, srčali pendžere, uređeno gazdinstvo, stoku i konje, poravnate i dobre putove itd. (2219-2334). Satir ga pohvaljuje i odgovara mu kako za to treba zahvaliti kraljici Mariji Tereziji i kralju Josipu, koji vode veliku brigu o Slavoniji. No unatoč tomu, ne propušta dodati još neke savjete u vezi s poboljšanjem uvjeta života i stanovanja te s očuvanjem sloge u porodici. Neki od njih su:

a) Poljoprivreda: Relković je vjerovao da je Slavonija majka mnogih naroda i da su joj Turci učinili strahovitu štetu uništivši njezine knjige, jezik i škole. Kritizirao je pametne domaće ljude koji mogu pomoći narodu, a ne čine ništa da se narod izvede na pravi put i uzdržava u moralu. Relković budućnost Slavonije vidi u poljoprivredi, u sjetvi. Njegova je seoska idila već u duhu romantizma. Piše, u oba izdanja, da je Slavonija zelena livada koja može roditi žitkom i svime što ljudima treba, samo treba pravilno organizirati oranje, s više truda i s više mara, te voditi brigu o gnojidbi.

b) Konjogojstvo i stočarstvo: Stoka je u Slavoniji jako stradala jer se držala na otvorenom, a nije se spremalo ni sijeno, pa su je hladne i duge zime desetkovale. Relković savjetuje stajsko stočarstvo i traži da se povede više računa o načinu držanja krava, osobito stoga što većina krava od listopada do proljeća nije davala mlijeka. Marija Terezija posebnu je pozornost posvećivala konjogojstvu, zbog ratnih i gospodarskih razloga (zaprežni i teretni konji), pa je s time povezana Relkovićeva tvrdnja da su iz Beča u Slavoniju poslali besplatne pastuhe.

c) Svinjogojstvo: Relković je kritizirao što se drži velik broj svinja na slobodnom, koje zimi pojedu svu hranu, a ljeti obole od kuge i nema od njih nikakve koristi. Svinje su prelazile i u Bosnu, i obratno, pa je sve to izazivalo veliki nered na tom području.

d) Svilarstvo: Relković u drugom izdanju Satira spominje nadzornika svilarstva Carolusa Sholengyja iz Lombardije, koji je donosio svilene bube da se svilarstvo ukorijeni i u Slavoniji te je ispričao slučaj jedne žene koja je uzela dva lota sjemena i za osam tjedana dobila 70 funti galeta, a za svaki funt 40 krajcara. Tako je zaradila više od 40 forinti. Relković potiče sadnju dudova jer u Vinkovcima osnovana svilara otkupljuje svu proizvedenu pređu.

f) Pčelarstvo: U drugom izdanju Satira Relković spominje Jantschin (poznati i cijenjeni učitelj) priručnik koji je objavljen na njemačkom jeziku pod nazivom Abhandlung vom Schwarmen der Biennen, a u Beču je 1790. objavljeno i drugo izdanje Hinterlassene vollständige Lehre von der Biennenzucht. Kasnije se to djelo 
dorađivalo i tiskalo u više izdanja i tijekom 19. stoljeća. Relković piše da se mnogi bave pčelarstvom, ali da se ljudi pritom moraju silno truditi ako hoće hasnu da imade.

g) Šumarstvo: U Relkovićevo se vrijeme šuma sve više cijenila i počela je njezina planska eksploatacija. U Italiji, Švicarskoj i Španjolskoj došlo je do manjka drva za ogrjev zbog devastacije šuma. Krajiške su vlasti počele braniti sječu bez odobrenja, što je izazvalo veliko nezadovoljstvo seljaka, koji su bili naviknuti koristiti drvo iz najbližih šuma i puštati u njih svinje na žirenje. No prave izmjere i odredbe o zaštiti šuma napravljene su tek poslije 1807. godine, kada je nadvojvoda Ludwig dao nalog za izmjeru šuma. Relković je istaknuo da šumu treba čuvati.

h) Kućne zadruge: Kao mnogi drugi u 18. i 19. stoljeću, i Relković je razmišljao o uzrocima zbog kojih zadrugarstvo ne pokazuje bolje rezultate u gospodarskom radu. On to opravdava neslogom te savjetuje kako da se ponašaju zadrugari kako bi zadružna kuća napredovala. Poziva na slogu i na poštivanje starijih, a u šestom poglavlju drugog dijela ilustrira to na primjeru mrava i pčela.

Relković navodi da najsrićnije jest stanje težačko (3269) te opisuje ljepotu, ali i težinu, seljačkog rada jer seljak proizvodi ono što svakom tribuje (3338) te da svoju robu uvik prodati more, jer jist valja, drugač bit ne more (3341-3342). Upozorava na ovisnost svih drugih o radu seljaka i kaže da zemlju ne treba osvajati oružjem, nego plugom, jer dat će ona prez svakog hinada, $i$ još višje, što se ti ne nada (3387-3388). Savjetuje skromnost i pita: O seljani dakle i oraču! Zašto tražiš kruha nad pogaču? Zašto želiš prominiti stanje, biti veći a imati manje? (34433444). Relković tvrdi da seljak ima mnogo više od pripadnika drugih staleža.

Gospodarske reforme prihvaćale su se u Slavoniji teško, jer ljudi nisu zaboravili »staro stanje « dok su bili pod Turcima, a već se trebalo prilagoditi na »novo stanje « pod Habsburzima. Trebalo je naučiti ljude da rade na zemlji kao da rata nikada više neće biti, a da istodobno budu spremni za rat, koji je mogao izbiti u svakom trenutku. Relkovićeve zasluge za preobražaj Slavonije uvidio je i dvor, a plemstvo s naslovom Ehrendorfski (von Ehrendorf) upućuje na njegovu ulogu časna djelovanja na selu. Relković poziva na poslušnost i na prihvaćanje novih običaja. Kao primjer navodi svilu i kako su svi bili protiv uzgoja, a sada se postižu lijepi uspjesi. Poziva na upornost, jer često s prvine nešto ne uspije, pa što jedne godine uspije, druge može potpuno podbaciti.

Njegova je kritika u prvom izdanju Slavoncima bila bolna, ali i uspješna. No njegove pouke i pohvale u drugom izdanju hvalevrijedne su i svakako pokazuju da se u tih sedamnaest godina, od jednog do drugog izdanja, mnogo toga promijenilo.

\section{Elementi katoličke obnove u djelu Satir iliti divji čovik}

U Hrvatskoj protestantizam nije uhvatio dubljeg korijena, ${ }^{6}$ no unatoč tomu, osvrnemo li se na razdoblje 17. stoljeća, uočit ćemo da se ipak može primijetiti težnja Katoličke crkve da utječe na život ljudi toga vremena. Kako ističe 
Georgijević, Katolička je crkva prije svega nastojala pobiti ostatke reformacije, nametnuti ljudima određena pravila ponašanja te zavladati njihovim mislima i osjećajima. Također, više je razloga zbog kojih je Katolička crkva posebnu pažnju poklanjala upravo našim krajevima. Prije svega, bilo je to zato što su tu čuvane tradicije o prvobitnoj crkvi, osnovanoj od samih apostola, potom zato što je prijetila opasnost za vjernike koji su bili izmiješani s pravoslavnima i muslimanima (što se poglavito odnosi na krajeve osvojene od Turaka) te stoga što je Katolička crkva zapravo imala i posebne političke ciljeve — njezina namjera bila je da $\mathrm{s}$ vremenom preotme Balkan Turcima i sjedini istočnu crkvu sa zapadnom. ${ }^{7}$

Što se tiče književnosti u Slavoniji u 18. stoljeću, ona je prije svega bila uvjetovana situacijom koja je u njoj vladala nakon odlaska Turaka. Kako su u to vrijeme jedini pismeni ljudi bili svećenici, tako je zapravo književni rad u Slavoniji u 18. stoljeću imao pretežito vjerski karakter. No, u vrijeme sedmogodišnjeg rata Austrije s Pruskom, od 1756. do 1763. godine, u književnost počinju ulaziti nove teme, ratni događaji, te tako književnost dobiva svjetovni karakter. Matija Antun Relković jedan je od pisaca koji je zaslužan za razvoj svjetovnog karaktera književnosti. Relkovićev zavičaj bila je Slavonija i to uzak pojas koji se zove Vojna granica ili krajina pa je tomu dijelu Slavonije Relković i posvetio svoju književnu djelatnost. ${ }^{8}$ Ipak, na svjetonazorskom se planu uočava kontinuitet koji povezuje 17. i 18. stoljeće, a upravo se ta svjetonazorska poveznica najopćenitije može odrediti kao odjek katoličke obnove. Kao što je primijećeno, i u raznim djelima koja su u svojoj osnovi zapravo djela svjetovne tematike, ipak možemo uočiti i isticanje različitih kršćanskih motiva. ${ }^{9}$ Relković svoje djelo piše inspiriran prosvjetiteljskim idejama, ali ipak ne možemo reći da je to prosvjetiteljstvo istovjetno onomu zapadnoeuropskomu. Te razlike idu dotle da i opravdanost uporabe tog termina postaje upitna. Naime, hrvatsko književno prosvjetiteljstvo ponajprije obilježava demokratičnost u smislu prilagodbe opusa književnomu ukusu široke, manje obrazovane čitateljske publike. Nadalje, iz korpusa hrvatske prosvjetiteljske književnosti gotovo da se i ne može izdvojiti djelo koje bi bilo posve sekularizirano, a kamoli djelo s materijalističkim ili pak ateističkim ideologemima. Upravo suprotno, kršćanski je nauk čest pratitelj tih djela, pa tako i Relkovićeva Satira.

Dakle, iako je Relkovićev Satir djelo prosvjetiteljskog, svjetovnog karaktera, u njemu ćemo naći i kršćanske motive koji potvrđuju koncept katoličke obnove kao pojave dugog trajanja. U pojedinim dijelovima Satira, Relković se Slavoncima obraća riječima koje su nalik propovijedi, što je također jedan od elemenata kojima se Katolička crkva služila u vrijeme katoličke obnove. Kako bi se uvidjelo koliko je, uvjetno rečeno, Satir propovijed, Kekez navodi da bi »ponajprije valjalo provjeriti je li Relkoviću najvažnije bilo gospodarski uzdignuti Slavoniju, kako se

7 Krešimir Georgijević, Hrvatska književnost od 16. do 18. stoljeća u sjevernoj Hrvatskoj i Bosni, Zagreb, 1969, 60 .

8 Isto, 216.

9 Davor Dukić, Hrvatska književnost: Neke temeljne značajke. Hrvatska i Europa: Kultura, znanost i umjetnost: Barok i prosvjetiteljstvo (XVII-XVIII. stoljeće), Zagreb, 2003, 487. 
uvriježeno drži, ili može biti prevladava moralno i vjersko htijenje« te zaključuje da je »na prvom mjestu bila moralna, a ne gospodarska sastavnica ${ }^{10}$ Bratulić iznosi da je »nakon reformacije Katolička crkva potražila put da se s pomoću propovijedi zacijeli ranjeno tijelo Crkve. Propovijedima je Katolička crkva htjela pokazati da je prebrodila krizu i da je u svome trijumfalnom pohodu krenula novim snagama kristijanizirati svijet. «11 Kako primjećuje Georgijević, »Crkva je, sa svojim vjerskim propisima, bila čvrsta osnova na koju se pisac oslanja u svojim dobronamjernim savjetima. Za izvođenje svog društvenog programa Relković se ne služi racionalističkom argumentacijom; on je za čuvanje starog reda stvari, koji se zasniva na principima kršćansko-katoličke vjere i crkve.«12

U djelu uočavamo brojne biblijske primjere koje Relković stavlja pred Slavonce. Na samom početku Satira Relković sam priznaje: "gdikoji redak Svetog pisma dotaknuo jesam $\ll^{13}$ Djelo daje najviše primjera iz Starog zavjeta, ali ponešto i iz Novog, pa tako Relković upućuje na grijeh prvih ljudi, veliki potop i kulu babilonsku, čime želi upozoriti Slavonce na grijehe koje su ljudi činili te posebno na kazne koje su ih nakon toga snašle, kako bi ih tako potaknuo da se drže Božjih zapovijedi i time si osiguraju dobar život. Također, Relković u predgovoru piše također: Indi gledaj kako se to dvoje skupa slaže: biti krstjanin, a obdržavat neznabožke običaje, koji su krstjanstvu škodljivi!! ${ }^{14}$ Naravno, sintagmom neznabožki običaji Relković upućuje upravo na Turke i njihove običaje, koji su i dalje ostali prisutni u Slavoniji i koji čine od Slavonaca loše kršćane.

Niz je primjera kojima Relković u tekstu upozorava na kršenje Božjih zapovijedi te želi uputiti Slavonce i Slavonke na njihovo poštovanje, pa ističe: i naučiš Božje zapovidi, nek krstjanski dobar život slidi (365-366). Tako s kršćanskog aspekta kritizira običaje koji su ostali od Turaka. Relković još piše: jer doista, tko god crkvu kiti, on od srčbe dragog Boga miti. Drugačije i prez bogoljubstva vaše znanje ne valjade ništa (283-286). Tim stihovima Relković želi poručiti puku da bez ljubavi prema Bogu njihovo znanje i djela ne vrijede ništa pa stoga moraju štovati Boga i činiti ono što je, prema kršćanskomu nauku, moralno ispravno.

Relković posebnu pozornost pridaje već spominjanim turskim običajima, odnosno turskim skulama, kojima se, kako iznosi Georgijević, »kvare patrijarhalni običaji i moral«. Georgijević jednako tako upozorava: »Tim 'skulama', smišljenim od Turaka, pisac suprotstavlja crkvu i prave škole: treba moliti majku kraljicu Mariju Tereziju da se u svakoj župi postavi meštar - učitelj, kao što je to u Madžarskoj, Moraviji, Češkoj.«15 Georgijević također ističe sljedeće:

10 Josip Kekez, Primjereniji pristup Relkoviću, u: Tomislav Bogdan (ur.), Matija Antun Relković $i$ Slavonija 18. stoljeća, Zagreb — Davor, 2000, 135.

11 Josip Bratulić, Propovjedna i hagiografska književnost, u: Ivan Supičić (ur.), Hrvatska i Europa: Kultura, znanost i umjetnost: Barok i prosvjetiteljstvo (XVII-XVIII. stoljeće), Zagreb, 2003, 533.

12 Krešimir Georgijević, nav. dj., 239.

13 Matija Antun Relković, Satir iliti divji čovik, Zagreb, 1988, 878.

14 Isto, 881.

15 Krešimir Georgijević, nav. dj., 263. 
Relković djevojkama preporučuje da se ugledaju u »Isusove drage zaručnice«, koje su prele kod svoje kuće $\mathrm{i}$ »učile pivat letanije«. U kolu djevojke pjevaju i sramotske pjesme, a u crkvi ih je stid započeti pjesmu »da proslave blaženu divicu«; u kolu pjevaju o Kraljeviću Marku i slave ga kao sveca. Slavonci trebaju da postave skule, škole, koje su »svete crkve stupi«, kad djeca odrastu, dodirivat će se »skuta božjeg«, primit će »Duha svetog «, pa će tako liječiti duhovne bolesti. ${ }^{16}$

Možemo primijetiti da Relković upućuje na još jednu Božju zapovijed, a to je štovanje same nedjelje kao dana posvećenog Bogu: Moja draga, Bog ne veli tako, neg on vami govori ovako: da šest dana sebi poslujete, a nedilju njemu poštujete (551- 554). Kao poseban grijeh koji Slavonci čine Relković ističe psovanje, odnosno navodi da muškarci uče djecu odmalena psovati vlastite majke i time ih navode na zlo i propast: Kojino se još ni najist kader, jer ga učiš već psovati mater? (327-328).

U VII. poglavlju njegova djela riječ je o posilu, odnosno međusobnom ogovaranju i zlim riječima koje žene jedne o drugima govore i o njihovoj oholosti, što je također jedan od sedam glavnih grijeha na koji Relković upozorava Slavonce.

Napominje da Bog uvijek nagrađuje one pravedne i vjerne: Gle što čini božanska pravica: da i onaj, koji virno služi, ako ga tko i nepravo tuži il ako mu podpuno ne plati, Bog to njemu posli nadoplati (786-790). Ali i kažnjava i kori one nevjerne: Al i slugu Bog nevirnog kara. Relković podučava i jutarnjoj molitvi i radu te kori zbog lijenosti i nemara, što Bogu nije drago: Ako Bog da ter živi budemo, valja da se rano probudimo i prikrstiv Bogu pomolimo pak za poslom svaki otidemo (1217-1220).

U poglavlju koje nosi naziv Moljba Relković govori o dobrim i nesebičnim djelima koje treba činiti, koja su Bogu draga i za koja će biti nagrađeni na onom svijetu: o tvom trošku, a ni od nje plaće, jer onamo teb' Sabaot daće (1329-1330). Relković progovara i o onom što Crkva uvelike osuđuje, a to su brakovi bez ljubavi: Jer kada vi svog sina ženite, ne pitate niti mu velite, je li njemu divojka u volji, hoće l' živit š njom u dobroj volji (1381-1384); Ženidba je sakramenat sveti, koga Isus baš glavom posveti (1579-1580). Na kraju ono najvažnije, Boga se treba bojati i štovati ga: Poštuj Boga za tvog stvoritelja i boj ga se, dila platitelja, pak cesara za upravitelja i zakona Božjeg branitelja (3465-3468).

Na temelju svega navedenog možemo zaključiti da Relkovićevo djelo sadržava veliki broj kršćanskih motiva i upozorenja na kršenje Božjih zapovijedi. Relković Slavonce upozorava da im ni samo znanje bez vjere i štovanja Boga neće značiti ništa. Stoga zaključujemo da u djelu možemo naći niz elemenata u vezi s kršćanskom vjerom, što će ujedno potvrditi i tezu o konceptu već spomenute katoličke obnove kao pojave dugog trajanja.

Relković je Satira napisao s pragmatičnim ciljevima, ali, osim što je nastojao potaknuti ekonomski, društveni te obrazovni napredak Slavonije, on želi potaknuti i vjerski napredak te dati pouke o kršćanskom moralu. Za njega je crkva bitna jer mu pomaže u poboljšanju naroda, a kako bi popravio tu stvarnost $u$ 
kojoj narod živi, Relković nastoji »oživjeti« moralne, tj. kršćanske norme svojih predaka te je njegovo djelo ispunjeno moralističkim prijekorima. ${ }^{17}$

\section{Ideološki aspekt Relkovićeva Satira}

Relkovićevo djelo postiže svoju idejnu i ideološku razinu na temelju nekih karakteristika samog lika Satira. Za razliku od tradicionalnih satiričkih oblika u kojima satiri kritiziraju prvenstveno karakterne osobine ljudi, Relkovićev Satir kritizira društvene pojave Slavonije u 18. stoljeću te se satirički osvrće na gospodarske prilike u Slavoniji. Lik Satira na tematskoj i idejnoj razini unosi u djelo svijest o drugačijoj, boljoj, naprednijoj koncepciji života i svijeta. Oblikovan kao prosvjetiteljsko biće, gubi neke svoje tradicionalne oznake satira, a zadobiva crte tradicionalnog divljeg čovjeka koji zagovara koncepciju prirodnog života kao najboljeg mogućeg. ${ }^{18}$

S obzirom na svoje sadržaje Relkovićevo je djelo bilo osobito zanimljivo onim književnokritičkim pristupima koji su i sami bili određeni sličnim ili podudarnim svjetonazorskim koncepcijama i opremljeni aksiologijom bliskom onoj koju nudi svijet Satira. To su oni književnopovijesni stavovi koji su, ističući empirističke, racionalističke, ali i materijalističke ideološke i idejne stavove oblikovane u $\mathrm{Sa}$ tiru, više željeli afirmirati vlastita svjetonazorska polazišta. Tako je Relkovićevo djelo, osobito u doba vladavine pozitivističko-marksističkih kritičkih paradigmi, bilo prosuđivano više s pozicija onih vrijednosti koje su bile na snazi u razdoblju proširenosti određenog književnopovijesnog ili književnokritičkog opisa negoli s pozicija svjetonazora ili pak povijesti mentaliteta 18. stoljeća.

Relkovićeva teološka shvaćanja u skladu su s metafizičkim optimizmom ranog prosvjetiteljstva. Svojom satirom nije dotaknuo ni jedan segment života u domeni crkvenih institucija. Kao što ne kritizira ni jednu instituciju crkvene vlasti te ne tematizira tada aktualna i često kontroverzna pitanja kršćanske teologije, tako Satir ne kritizira ni jednu instituciju svjetovne vlasti. »Sadržaji koji oblikuju Relkovićeve poglede na te strukture društvene moći uvijek su eksplicirani legalistički i konformistički. «19

Bez obzira promatramo li Relkovićevo djelo kao relikt klasicističke idile ili kao pučko-prosvjetiteljsko djelo, njegov je Satir inovativan i posve specifičan u kontekstu kulture 18. stoljeća, ali s ostalim djelima tog razdoblja dijeli utilitarističku funkcionalnost.

Relkovićeva je nakana bila ispravljanje starih nevaljalih običaja. Pri toj nakani on je svjesno falsificirao provenijenciju slavonskih narodnih običaja, označavajući ih turskima. U njima je vidio uzrok retardacije, zaostajanja za europskim modelima

17 Ekrem Čaušević, Turci u Satiru Antuna Matije Relkovića (1732. — 1798.), Prilozi za orijentalnu filologiju, Sarajevo, 1999, 4.

18 Dunja Fališevac, Kaliopin vrt II, studije o poetičkim i ideološkim aspektima hrvatske epike, Split, 2003, 221-232.

19 Isto, 130. 
življenja. Činjenica da se ti običaji u Relkovićevoj interpretaciji atribuiraju turskima, a ne kršćanskima, može se tumačiti ne kao izraz vjerske netolerancije, nego kao svjesna autorova nakana da se argumentacija prilagodi spoznajnom horizontu recipijenta, slavonskog seljaka. ${ }^{20}$

I u prvom i u drugom izdanju Relkovićeva Satira Turci su prikazani u najgorem mogućem svjetlu. Razlog tomu je snažan utjecaj prosvjetiteljskih ideja, privrženost Habsburškoj Monarhiji, politici i idejama apsolutističkih, reformatorskih i prosvjetiteljskih vladara Marije Terezije i Josipa II. te jak kršćanski svjetonazor, iz kojeg su zračila snažna antiturska raspoloženja. Slavonija je nakon izgona Turaka doista zaostala u gospodarskom, kulturnom i prosvjetnom pogledu u odnosu na Monarhiju i ostale europske zemlje. Relkovićevi su turcizmi krajnje odbojni. Neke od njih koristi samo s negativnim konotacijama pa tako »turcizam hadet (= adet) koristi samo ako spominje zle turske hadete, a riječ običaj uvijek kad govori o lipim slavonskim običajima. Zbog te odbojnosti, u drugome je izdanju svoga djela nastojao zamijeniti neke turcizme riječima iz slavonskoga jezika $\ll^{21}$

Relković, unatoč vrlo odbojnomu stavu prema riječima turskog porijekla, u svojem djelu koristi mnoštvo turcizama. Razlog tomu je njihova frekventnost u jeziku domaćega puka dpa ih naprosto nije bilo moguće eliminirati. Neke hrvatske riječi zamijenio je turcizmima, vjerojatno zbog nepoznavanja turskog jezika. Čaušević u radu 'Turci' u Satiru Antuna Matije Relkovića (1732. - 1798.) ističe kako neki hrvatski lingvisti smatraju da se u Relkovićevu slučaju može govoriti »samo o teorijskome purizmu«, a ne o stvarnoj nakani pisca da spomenute tuđice pokuša zamijeniti »slavonskim « riječima. Josip Vončina smatra da je pisac iznevjerio načelo »da svoj jezik oslobodi turcizama« s ciljem da ostane bliži i razumljiviji seljaku.

Premda je divan osuđivao kao loš običaj u Slavoniji 18. stoljeća, Relković koristi strukturu divana, priskrbljujući tako svojemu djelu popularnost, komunikativnost, pristupačnost te moć učinkovita djelovanja na polupismene recipijente. ${ }^{22}$ Iz toga možemo zaključiti kako se u djelu pojavljuju i proturječni ideologemi.

\section{Zaključak}

O Relkovićevu Satiru naviknuli smo govoriti kao o djelu koje je izrazito prosvjetiteljskog karaktera. Naravno, to je potvrdio niz pragmatičnih motiva kojima Relković nastoji podučiti stare Slavonce, a osobito one mlade koji će sudjelovati u daljnjem unapređivanju Slavonije, a koji već sada žive u neznanju. U djelu se može uočiti i niz kršćanskih motiva, kojima Relković s jedne strane kudi Slavonce zbog svih loših navika te odmetanja od Boga i njegova nauka, a s druge ih strane nastoji podučiti što im valja činiti kako bi se opet mogli smatrati pravim

20 Isto, 125.

21 Ekrem Čaušević, nav. dj., 10-11.

22 Anica Bilić, Mali i(li) zanemareni pisci, studije i eseji, Zagreb - Vinkovci, 2004, 157. 
kršćanima i time steći vječni život na nebu. Dakle, možemo zaključiti da se Relković ne suprotstavlja nauku Katoličke crkve, nego i vjersku komponentu smatra vrlo bitnom, što njegov Satir iliti divji čovik čini reprezentativnim djelom hrvatske književnosti 18. stoljeća.

Ideational Strata of the Enlightenment and Christianity in Relković's The Satyr Krunoslav Matošević*

\section{Summary}

The paper looks into one of the most important literary achievements of the Croatian Enlightenment, the work, Satir iliti divji čovik [The Satyr or Wild Man] by Matija Antun Relković. The first section presents a brief biography of the author and a localization of his creative activity with a list of his major works. The greater part of the paper is devoted to portraying elements of the Enlightenment which in the work have been treated by way of social, moral and cultural issues. In various works which illustrate topics which are in their essence worldly, we can still note a certain emphasis on Christian motifs, this being the case with The Satyr; therefore, this paper will describe elements of the Catholic renewal which may be found in the work. The fourth section follows with a general overview of social, ideational and world-view components by means of which it will be demonstrated that the dominant components in the work are faith in effecting change in man's being through education and also the conviction that school and schooling provides students with moral-ethical values. This would prove that Relkovićs contemporary world-view and contemporary view of man is not in conflict with religious aspects.

Key words: Relković, Satyr, Enlightenment, Catholic renewal, world-view concept

* Krunoslav Matošević, M.Ed. E-mail: kruno.matosevic26@gmail.com 